\title{
Moral Education and Quality Assurance of Nigerian Secondary Schools
}

\section{Ogundele, Michael Olarewaju Ph.D}

\author{
Department of Education Foundations, Faculty of Education, University of Jos, Nigeria \\ michogun63@gmail.com \\ Jimba, Noah Daku Ph.D \\ Department of Education Foundations,, Faculty of Education, University of Jos, Nigeria \\ jimbadaku@yahoo.com

\section{E.R Peter Luka} \\ Department of Education, Gombe State, University, Gombe, Nigeria \\ erlucaser@yahoo.com
}

Doi:10.5901/ajis.2016.v5n1p323

\begin{abstract}
The study examined the moral education for enhancing quality assurance of secondary education. The study explains the concepts, the purpose and needs for moral education as an effective way for enhancing quality assurance in the society. It was however concluded that with the integration of moral education in Nigerian secondary schools, the quality of the certificates acquired will be enhanced and the high integrity will be accorded by the members of the society. The paper however suggested strategies for integrating moral education into Nigerian secondary schools in the interest of enhancing quality assurance in the secondary education system. The effective integration of moral education will surely accord high integrity for the candidates, the schools, the certificates and the society in general.
\end{abstract}

Keywords: Moral Education, Quality Assurance and Secondary Schools.

\section{Introduction}

It is an undisputable fact that education is the only instrument for enhancing national transformation and sustainable development. As Ogundele (2015) rightly said that any nation that toyed with her educational provision to her citizens, such nation can never be ranked high among other developed nations at the global level.

It is therefore pertinent to note that everyone wants quality assurance in their children education this is to say that, no parents want to toy or joke with the educational quality of their children as such parents and teachers cooperate together in the total development of their children. Jaiyelola (1990) noted that, for any citizen to have quality education he or she must be morally and emotionally sound. Moral value therefore becomes a key word for a quality education provided at all levels. Ukeje (1998) also opined that moral value must be adequately reflected in the behaviours of an educated man. Adeyemo (1990) also stated that immoral behaviours and attitudes have a baneful reflection on the quality of individual education received. The author however noted that an educated person that is not morally sound in the society, the quality of the certificate received at the school system will be disrespected in the society. The author however conducted that it is better for such individuals not to go through, schooling; than bag high degree and find wanting in the areas of moral value. Jimba, Ogundele and Damal (2015) also, said that for any person in the position of authority to be accorded high respect in the society, they must be morally and emotionally sound. Moral value orientation is therefore important in the school system, for the quality of the education provided in such schools to be assured. Owan, Enoh and Bamangah (1992) morally behaved individuals in the society lead to high respect at both national and international communities. The certificate acquired will also be accorded high respect and the quality of such certificate will be adequately assured.

This paper therefore defined the moral education, quality assurance, the types of immoral behaviours that hampered the quality of secondary education, the need for moral education in schools, the indicators of quality assurance in the schools. The important of moral education on the quality assurance of secondary education and the strategies for 
integrating moral education into secondary education curriculum in order to enhance quality assurance in secondary education especially in Nigeria.

\section{Moral Education and Types of Immoral Behaviours in Schools}

Morality according to Jimba (2015) is the act of being creditably standard, valued and respected in all aspect of behaviours in the society. The author noted that an individual that is not culturally, behavioural and emotionally respected in the society such an individual cannot command the respects of all and sundry members of the society. In the same vein, Ogundele (2015) stated that for every member of the society to be morally sound and command the respects of every citizen in such society, such person must respect the cultural value of the land, avoidance of any act or behaviours that contradict the traditional value of the society, giving adequate respects to the elders, language, religious tolerance and adequately involvement in the communal efforts of the society. Such person will be respected and high esteem will be given to such individuals. The author also went further to say that any member of the society that are morally sound, respected and stick to the good of the land and avoid the bad of the land such person will be adequately respected and whatever he does will also be recon with such society.

The need to identify good and moral behaviours, attitude knowledge and skills are therefore important and to be instilled in the mind of the young generation. Since every community has moral code which is an important and the major concern of the adult member in the society to instill in the minds of the young ones. The moral education programme is now becoming a shared responsibility of the school and the community within the society.

However, moral education is therefore refers to the systematic ways of helping the children to acquire those moral habits that will help them individually to have good living and become a respected, productive and contributing members of their communities. The need for the youths in the citizens to acquire those behaviours that will give them high respect is therefore integrated into Nigerian educational system. Tony (2004) described moral education is the training and inculcating those desirable characters, habits, culture, attitude and behaviours in the youths, so that they will be able to differentiate between the good and bad moral value and understand the rationale for their choice of their action that will command good respect for him in the society.

Adeyinka (1991) identified the series of immoral acts that are perpetrated among the students. The author however noted that those immoral acts relegated the quality of education to background. The high perpetration or immoral acts and behaviour among the erring students diminished the integrity of the certificates and the rate of education received. Those immoral identified as being perpetrated in the school system are cultism, examination malpractices, bullying, killings, terrorisms, religious intolerance, sexual harassment, indecent dressing, loose languages, bribery, truancy, absenteeism, prostitutions, lateness to school, poor time management, gossiping, student interest, thurgery, arsons, disobedience, disrespect to the constituted authority, arsons and noise making. The perpetration of immoral acts in the society has baneful effects on the quality assurance and students' academic performance. The high impetus to the relegation and stigmatization of the schools, individual and the certificate received in the schools. However, the integration of moral education into the school programme will therefore reduce high rate of immoral behaviours perpetration in the schools. It is therefore important to note that moral education is an effective tool for enhancing quality assurance in the education programme received both during the schooling and after the school programme.

Ogundele (2015) stated that any school where there are high rate of in disciplinary behaviours, the parental patronage, students' enrolment, accessibility and quality assurance are at stake. The reason being that no member of the society will respect or give high esteem to any schools where high there is perpetration of immorality act. Also, low integrity is accorded to the individuals that are found wanting in the aspect of immorality. However, in order to accord high integrity and quality to the education provided and received in the school system moral education in the school system are therefore inevitable. Ogundele, Gyot and Bwoi (2014) stated that it is an immoral act that in the schools that encourage high rate of unemployment, falsification of results, cheating during examination, and suspicions of individual dealings and the aftermath of immoral behaviours in the society do stigmatize such society, schools certificate and individuals. As the authors rightly put that good name are better than riches. That if you acquire high qualification or you are very rich in the society nobody will accord you any respect nor give you high esteem. If such an individual is not morally sound: integration of moral education will therefore enhance adequate moral behaviours that will inculcate good behavious among the students and to build them for the future respect for the society. Odediran (2000) cited examples of the immoral behaviours in the society which had caused a lot of disrespect for the universities, individuals and the certificates itself. Example cited was the purchase of certificate by Salisu Buari, at university of Toronto. The culprit was the former speaker of the House of Representative. However, when the secret was leaked to the public, Salisu Buari was 
impeached and up till today, any fake result or suspected back result is then termed as Toronto result. The name spoiled up till today.

Also cited examples of immoral behaviours that are perpetrated in the society, as follows sexual harassment, prostitutions, examination malpractices, cultism, bullying, thurgery, killings, divorce, cheatings, smoking, truancy, absenteeism, raping, homosexualism, lateness, falsification of results and lack of respect and disobedience to the people in the position of authority. It is therefore important to note that high rate of moral decadence in the society have baneful effects on the quality assurance and students' academic performance in the school system.

Nnenna (2004) also noted that any school or individuals where there are high rate of moral decadence such schools would have low parental patronage low students enrolment and low students accessibility to the educational provision in that society. The author also stated that no societal member will respect the integrity of those schools with high rate moral decadence. That society will not humour the certificate or results that are acquired from such schools. That immoral acts or moral decadence in the school constitute low integrity to the type of education programme provided to the youths. Zubair (2011) said that the penetration of students in different types of immoral acts in the schools bring about high rate of unemployment because the certificate received or presented will be given high suspicious and demand through verification.

\section{Purpose of Moral Education in the School System}

The need for moral education in the school system is thereby advocated for moral education programme is therefore important for the following purpose:

To enhance the integrity of the schools: Integrity of the schools, individuals, the society and the certificates required in the school system is therefore important. Integrity of the school where there is perpetration of different immoral acts is at stake. As Adeyemo (1998) rightly put that no parent nor society nor international community will give respect to any school where there are high rate of cultism, examination malpractices, sexual harassment, lateness to the schools, lack of respect to the constituted authority etc. however in order to enhance high integrity to the school stakeholders and the educational programme in the school, there is the need to integrate moral education into the school curriculum.

Accessibility to Quality Education is totally ensured: It is important to note that when the school system is conducive for effective teaching learning process, every member in the society will be interested in sending their children into those types of schools. However, George (2015) supported the view that moral decadence in the society has baneful effects on the quality of education provided in the schools. The author stated that the high perpetration of immoral behaviours like examination malpractices, robbery, thurgery, smoking, cultism, witchcrafts, sexual harassment, prostitution, abortion, relegate the integrity of such schools. No parent will have happy accessibility to such schools, because no respect will be accorded to such a school. However, in order to accord high accessibility to the school system moral education should be integrated to the school curriculum.

Moral education in the school system enhance internal efficiency: With the introduction of moral education into the school, every student, teacher and member of the school will acculturate disciplinary behaviours. The rate of absenteeism, truancy, repetition, wastage, failure will drastically reduce in the school. Ogundele and Oparinde (2013) was of the opinion that quality control of school programmes will surely aid internal efficiency indicators in the school system and good name of the school will adequately be enhanced in the school.

Moral education will aid quality assurance and students' academic performance: The certificates received in the school and personally of the graduates of the schools where there are no moral decadence will be adequately respected in the society. As Hocking (1990) rightly put it that any educated man that was morally trained in the school system will be morally sound while in the society, such individuals that is morally sound will be accorded high integrity and the certificates and qualifications acquired will be accorded high respect in the society.

Also, moral education in the school system encourages right conduct that will require commitment and high consistency of the stakeholders in the society: It will therefore inculcate right values, attitudes, habit and be able to take a right decision for any action taken. Kelvin (1991) the integration of moral education into the school will help in the inculcation of right attitude, skills, knowledge, honesty, kindness, forgiveness and cooperation and all attitudes that will command high respects to the qualification acquired in the schools.

Moral education will command good respects for the cultural value of the society: Nkom (2005) stated that any education received or certificate acquired that does not give cultural respect to the society, such education will not be respected by the society for instance professors or doctors, lawyers or the engineers that don't have respect to the 
greetings, traditions, dressing code, respect for the law of the land, respect to the constituted authorities will never be accorded respect by the society. The integrity of such educated man cannot be ranked high in the society moral training will encourage high respect to the cultural value of the society.

Finally, moral education will develop good compatriots: Religious tolerance, ethical issues and develop all aspect of citizenship and value orientation in the mind of the students, so that when they graduate from the schools they will become a responsible member of the society. The people will therefor become somebody to be reckoned with in the society and at the global levels.

\section{Conclusion}

Due to the moral decline of the youths in the media/secondary schools and the bitter complaints of the stakeholders in the education moral education therefore expensively discussed on the need to integrate moral education and the strategies for integration into the secondary school programme. It could be concluded that effective integration of moral education into the secondary schools curriculum. The integration will surely eradicate moral decadence in and out of the schools. It is therefore important to note that the perpetration of moral value and moral convictions in the schools give high quality and integrity into the education provided and the certificates acquired will be accorded high respect in the society.

\section{Strategies for Integrating Moral Education in Nigerian Schools}

Evidences in the abundant literature on the moral decadence in the society have relegated the progress of Nigerian education programme. However, in order to enhance quality assurance in the students' academic performance in Nigeria. It should be noted that there are growing concern over the years about gradual moral decay and loss of ethical value with society. The cankerworms seem to have drastically affecting the educational system. Unfortunately, members of the public keep shifting blames as to who is to be held responsible for the menace that is the parents, teachers, students or the government. The paper therefore examined all the issues relating to moral education and their implication for quality assurance and students' academic performance. The issue therefore called for the need to integrate moral education into Nigerian educational system. However, strategies for integrating moral education into the secondary school curriculum in Nigeria are:

Provision of educational services for the students and staff in the school: The schools need to provide adequate educational services like counseling services, vocational services, religious services, welfare services, recreational services in the school system. It should be noted that the provision of the essential services will modify individual students and make them relevant and responsible to the society.

Teaching of civic education, moral education, religion education citizenship education and government in the school system will surely assist in training the youth on the spirit of togetherness, belongingness and national integrations and all minds that will enable individuals to behave well.

Furthermore, formation of formidable associations and clubs will inculcate spirit of citizenship and leadership in the mind of the students; it should be noted however that belonging to a club and society in the school will monitoring help individuals against bad behaviours.

Also, moral education can be integrated into the school curriculum through the use of the available resources in the schools. As Ogundele (2001) stated that community resources can be used to teach moral education. The author identified community resource like courts, banks, National Assembly, ministries, prisons and post offices can be visited to see the caliber of people and the facilities in operation worthy of emulation. The author went further to say that worthy and people of integrity can be invited by the schools to come and give moral talk career choices etc. The use of the resources available will aid moral education and moral value among the school aged people and when individuals are morally sound right from the schools, the certificates bagged will be accorded respect in the society.

The use of educational videos and films should be encouraged in the schools system. The teachers and parents should try to monitor the students on the type of videos and films that the students view while in the school and at home.

There should be effective use of social media, according to Etejere and Ogundele (2015), the teachers should make use of social media to give assignment, test, research topics and online examinations to the students. The effective usage of social media will reduce the use of social media for immoral acts or immoral behaviours in the society.

Also, the government should encourage the provision of feeding to the school system. Dokatry (2014) suggested that for the moral decadence to be reduced in the society, the government should provide lunch for the pupils while in the schools. The author noted that hunger constitute the major cause of the moral decadence in the society. When a child is 
hungry he will not hesitate to partake on any immoral act that can give food reward. The introduction of school feeding by the government will eradicate the perpetration of immoral act within and outside the schools. The governmental efforts will enhance quality assurance in the education and the integrity of the education will be enhanced,

Finally, Kumuyi (2011) also called for the preservation and protection of children dignity through avoidance of child abuse, child labour and child neglect. The author however suggested that the problem could be effectively managed through provision of effective guidance and counseling services in the schools, regular, health education, drastic steps against the culprits that violate the laws and edicts of child right and dignity and improved condition of service and standard of living to reduce or alleviate poverty of the parents and other members of the society.

\section{References}

Adeyemo, P.A. (1990). Principles and Practice of Education. Lagos: Macmillan Press.

Adeyinka, A.A. (1991). Introduction to Philosophy of Education. Ilorin: University Press.

Dokatry, D.O. (2014). Home grown feeding and quality of primary education in Jos North Local Government Area of Plateau State, Nigeria: unpublished M.Ed desertation University of Jos, Nigeria.

Enoh, A, Owan. A \& Bamanga, J.B. (1992). Handbook on Educational Foundations. Jos: Juvelline.

George, F. (2015). Investigation on Moral decadence on Academic Performance of Secondary School Students in Kaduna State. Counseling Intervention: Unpublished M.Ed desertation of University of Jos, Nigeria

Hocking, D. (2014). Moral Catastrophe. Oregun: Harvest House Publishers.

Jaiyeola, .G. (1990). Contemporary Issues in Nigerian Education. Ilorin: Success Press.

Jima, D.N. (2015). Understanding Philosophy of Education. Ankpa: Rotak Press.

Jimba, D.N, Ogundele, M.O \& Damal, D. (2015). The role of ethics in enhancing accessibility to Nigerian Education. A paper presented at the $35^{\text {th }}$ Annual National Conference of the Philosophy of Education Association of Nigeria. Held on $27^{\text {th }}-30^{\text {th }}$ October, 2015 at Nasarawa State University, Keffi.

Kelvin, T.S. (1991). Education and Social Problems in the Society: Issues and Risks. International Journal of Sociology of Education. 13 (2) $16-22$

Kumuyi, F.O (2011). Child Abuse and Students' Academic Performance of Secondary Schools in Irepodun Local Government Area, Kwara State unpublished PGDE project of National Teachers Institute, Kaduna.

Mmaki, N.M (2011). Teenager Early marriage and Pupils Academic Performance of Primary Schools in Ohaozara LGA, Bayelsa State. Unpublished PGDE project of National Teachers Institute, Kaduna.

Knom, S.A (2005). Moral Choices. Michigan: Zondervan Press

Odediran, J.A (2000). Essentials of Guidance and Counselling Programme in Schools. Ilorin: University Press.

Ogundele, M.O. (2015). Moral Education and Quality Assurance of Secondary Schools in Nigeria. A paper presented at the Career day of Cherubim and Seraphim College Jos held on 22nd October 2015.

Ogundele, M.O, Gyot, B.\& Bwoi, G.M (2014). Towards Resolving Ethical Issues for enhancing Educational Research Integrity in Nigeria. Asian-Pacific Journal of Multidisciplinary Research 4 (2), 15-23.

Ogundele, M.O, \& Oparinde, R.O. (2013). Child Abuse and Administrative Effectiveness of Secondary Schools in Kwara State, Nigeria Sokoto Educational Review 13 (1) 145-159.

Tony, J.O (2004). Towards Eradicating Early Child Marriage in Nigerian Schools. Role of the Stakeholders. International Journal of Counselling Education. 3 (3), 7-13

Ukeje, A.B (1998). Educational Foundations. Owerri: Javelline Press.

Zubair, G.A (2011). Essentials of Philosophy of Education. Lagos: Naboth Press. 
